\title{
Pembentukan kematangan karir pemuda minangkabau melalui budaya baliak ka surau
}

\author{
Aulia Latifa ${ }^{1 *}$, Firman ${ }^{1}$, Riska Ahmad ${ }^{1}$ \\ ${ }^{1}$ Pasca Sarjana Bimbingan dan Konseling, Universitas Negeri Padang, Indonesia \\ ${ }^{*}$ Corresponding author, e-mail: aulialatifa016@gmail.com
}

\begin{abstract}
Remaja memiliki beberapa tugas perkembangan, diantaranya yaitu memilih dan merencanakan karir, apabila remaja mampu menyelesaikan tugas tersebut maka dianggap telah mencapai kematangan karir. Banyak faktor yang mempengaruhi kematangan karir pada individu, salah satunya yaitu faktor eksternal berupa lingkungan sosial budaya. Suku Minangkabau dikenal budaya tinggal di surau bagi pemuda. Surau di Minangkabau selain memiliki fungsi sebagai tempat beribadah namun juga juga berfungsi sebagai lembaga pendidikan islam tradisional tidak hanya untuk meningkatkan kemampuan intelektual namun juga untuk membentuk karakter dan kepribadian pemuda Minangkabau melalui kegiatan belajar agama, nilai-nilai kehidupan, bersilat, keterampilan berkomunikasi. Kemudian pada akhir tahun 50-an, eksistensi surau di Minangkabau mulai menurun dikarenakan terjadi pergolakan Pemerintahan Revolusioner Republik Indonesia (PRRI) di Sumatera Barat yang menimbulkan trauma psikologis bagi masyarakat Minangkabau sehingga mulai meninggalkan identitas Minangnya, salah satunya budaya tinggal di surau. Ketika zaman reformasi, melalui UU No. 22 Tahun 1999 Minangkabau kembali menggalakkan budaya tinggal di surau dengan gerakan Baliak ka Surau. Dimana dalam teknis pelaksanaannya direlevansikan dengan kemajuan zaman di abad ke-21 ini. Kajian ini menggunakan metode kepustakaan (library research). Tujuan dari tulisan ini yaitu menyajikan analisis kematangan karir pemuda di Minangkabau melalui Budaya Baliak ka Surau. Budaya Baliak ka surau perlu kita lestarikan mengingat kompleksnya fungsi dan manfaat surau bagi pemuda Minangkabau.
\end{abstract}

Keywords: Kematangan karir, surau, baliak ka surau

Article History: Received on 12/1/2021; Revised on 26/1/2021; Accepted on 13/2/2021; Published Online: 20/2/2021.

$\begin{array}{r}\text { (c) (i) } \begin{array}{r}\text { This is an open access article distributed under the Creative Commons Attribution License, which permits unrestricted use, } \\ \text { distribution, and reproduction in any medium, provided the original work is properly cited. (C2017 by author. }\end{array} \\ \hline\end{array}$

\section{INTRODUCTION}

Manusia melewati tahap-tahap perkembangan sepanjang rentang kehidupannya. Dimana pada setiap tahapnya terdapat tugas perkembangan yang dipraktikkan oleh individu. Remaja adalah sebuah masa yang menjadi salah satu tahapan perkembangan yang dilewati individu. Menurut Havighurst (dalam Yusuf, 2006) salah satu tahapan yang harus dilewati oleh seorang remaja adalah memilih dan merencanakan karirnya. Apabila remaja mampu menyelesaikan tugas ini, maka dapat dikatakan remaja itu 
memperoleh kematangan dalam karirnya. Super (dalam Siti S. Fadhilah, 2010) berpendapat kematangan karir ditandai dengan siap atau tidaknya seseorang dalam mengenali dan mengatasi masalah-masalah pekerjaan. Jadi kematangan karir dapat dilihat dari sejauh mana seseorang individu berhasil menguasai tugas-tugasnya yang sesuai dengan perkembangan karir.

Terdapat empat buah faktor yang berpengaruh terhadap kematangan kehidupan karir seseorang, yaitu sebagai berikut: faktor genetik, faktor belajar, faktor lingkungan dan faktor keterampilan menghadapi tugas (task-approuch skills) Krumboltz (dalam Munandir, 1996). Faktor lingkungan mempengaruhi cara mengambil keputusan kerja, seperti kesempatan kerja (apa, dan berapa banyak), kemudian kesempatan dalam pendidikan dan pelatihan negeri, swasta, formal dan nonformal. Faktor ini menjelaskan perihal indeks kematangan karir individu berkorelasi dengan tingkat pekerjaan orang tua, kurikulum kampus, stimulus budaya serta kohesivitas keluarga (Nurillah, 2017). Faktor Lingkungan sosial budaya dimana orang dibesarkan. Lingkungan ini luas sekali dan berpengaruh besar terhadap pandangan dalam banyak hal yang dipegang teguh oleh setiap keluarga (Winkel, 1997). Kemudian dukungan sosial memberi pengaruh terhadap kematangan karir individu. Salah satu bentuk dukungan sosial menurut Saravino 2002 adalah dukungan jaringan sosial, dimana dukungan ini mampu membuat individu merasakan bahwa dirinya merupakan bagian dari suatu kelompok yang mana anggotanya dapat saling berbagi.

Sebagai salah satu suku di Indonesia, Minangkabau memiliki Budaya yang unik yaitu budaya tinggal di surau bagi laki-laki Minangkabau yang telah memasuki usia sekolah 6 sampai 7 tahun hingga usia 15 tahun. Pendidikan surau lebih merupakan suatu proses belajar untuk sosialisasi dan enkulturasi kultural (Azra, 2003). Surau adalah sebuah institusi yang khas dan tipikal Minangkabau. Surau bukan hanya tempat shalat, melainkan tempat anak muda untuk tidur dan mendapatkan "pengajaran". Dimana pengajaran yang nantinya berguna untuk bekal hidup. Di suraulah tempat anak muda berlatih dan memperoleh bekal untuk hidup. Surau sebagai tempat untuk mengaji, belajar pidato dan berpasambahan, mengubah perilaku dari yang bersifat kekanak-kanakan ke orang dewasa, dan belajar bersilat (Syafri, 2004).

Selanjutnya surau juga berfungsi sebagai Pembentukan watak dan perilaku lakilaki dan perempuan minang; Belajar agama, belajar membaca alquran; Penggemblengan anak muda membuat mereka tegar dan survive di rantau; Membangun interaksi sosial (N. Latif, 2002). Begitu kompleksnya fungsi surau bagi pemuda Minangkabau, layaknya sebuah lembaga pendidikan, pendidikan di surau tidak hanya untuk meningkatkan kemampuan intelektual namun juga untuk membentuk karakter dan kepribadian serta mengasah skill pemuda Minangkabau. Dimana kesemuanya itu menjadi faktor yang dapat mempengaruhi kematangan karir seorang individu.

Kebudayaan tinggal di surau telah banyak melahirkan tokoh pendiri bangsa, khususnya dari Minangkabau seperti Buya Hamka, Bung Hatta, H. Agus Salim dan Tan Malaka yang merupakan hasil pendidikan surau. Dari tokoh-tokoh tersebut dapat 
diketahui bahwa, surau memiliki peranan penting dalam pembentukan karakter individu yang nantinya akan berguna bagi masyarakat. Namun, dalam perjalanannya pada akhir tahun 50-an, eksistensi surau di Minangkabau mulai menurun dikarenakan pada tahun tersebut terjadi pergolakan Pemerintahan Revolusioner Republik Indonesia (PRRI) di Sumatera Barat yang mengakibatkan pertumpahan darah. Hal ini menimbulkan trauma psikologis bagi masyarakat Minangkabau sehingga mulai meniggalkan identitas Minangnya, salah satunya budaya tinggal di surau.

Pada era reformasi keluarlah Undang-Undang No. 22 Tahun 1999 tentang Pemerintahan Daerah yang memberikan kebebasan kepada daerah untuk melakukan revitalisasi nilai-nilai tradisional masing-masing daerah. Sehingga masyarakat Minangkabau kembali menggalakkan budaya yang sempat ditinggalkan, salah satunya budaya tinggal di surau dengan gerakan Baliak ka Surau. Dimana dalam teknis pelaksanaannya direlevansikan dengan kemajuan zaman di abad ke-21 ini.

\section{METHOD}

Penelitian ini adalah penelitian studi pustaka (literatur research). Metode yang menghimpun data dan informasi yang diperoleh dari berbagai sumber, bisa buku, artikel, dan sumber lainnya yang berkaitan dengan topik atau permasalahan dari tujuan penelitian ini. Dalam penelitian ini, terdapat langkah yang dilakukan, yaitu sebagai berikut: 1) menentukan topik penelitian, 2) menghimpun data, 3) menentukan tujuan penelitian, 4) penyajian data, 5) penarikan kesimpulan.

\section{RESULTS AND DISCUSSION}

\section{Kematangan Karir}

Manusia melewati tahap-tahap perkembangan sepanjang rentang kehidupannya. Dimana pada setiap tahapnya ada tugas-tugas perkembangan yang harus dilakukan oleh individu. Masa remaja merupakan salah satu tahapan perkembangan yang harus dilewati oleh individu. Menurut Havighurst (dalam Yahya, Maalip, \& Omar, 2011) salah satu tugas tersebut adalah memilih dan merencanakan karir. Apabila remaja mampu menyelesaikan tugas ini, maka dapat dikatakan remaja tersebut memperoleh kematangan karir. Super (dalam Siti S. Fadhilah, 2010) berpendapat kematangan karir ditandai oleh siapnya seseorang dalam mengenali dan mengatasi masalah-masalah pekerjaan. Kematangan karir yaitu sejauh mana seseorang individu berhasil menguasai tugastugasnya yang sesuai dengan perkembangan karir.

Terdapat empat faktor yang berpengaruh terhadap kematangan karir seseorang, yaitunya: faktor genetik, faktor lingkungan, faktor belajar dan faktor keterampilan menghadapi tugas (task-approuch skills) Krumboltz (dalam Sastrawati et al., 2019). Faktor lingkungan memberi pengaruh terhadap pengambilan keputusan kerja, seperti kesempatan kerja (apa, dan berapa banyak), kesempatan pendidikan dan pelatihan (formal, nonformal, negeri, swasta). Faktor ini menjelaskan indeks kematangan karir individu berkorelasi dengan tingkat pekerjaan orang tua, kurikulum kampus, stimulus budaya dan kohesivitas keluarga (Nurillah, 2017) .

Kemudian faktor lingungan social budaya, tempat dimana individut lahir dan dibesarkan. Lingkungan yang dimaksud memiliki makna yang luas serta memberi 
pengaruh yang besar terhadap pandangan dalam banyak hal (Winkel, 1997). Kemudian dukungan sosial memberi pengaruh terhadap kematangan karir individu (Listyowati et al., 2012). Salah satu bentuk dukungan sosial menurut Saravino (2002) adalah dukungan jaringan sosial, dimana dukungan ini mampu membuat individu merasakan bahwa ia menjadi bagian dari kelompok yang peduli dengan suluruh anggotanya.

\section{Surau}

Merujuk pada Kamus Besar Bahasa Indonesia, surau diartikan sebagai sarana atau rumah bagi umat muslim untuk melakukan ibadahnya seperti shalat dan mengaji. Selain sebagai tempat beribadah di Minangkabau surau juga berfungsi sebagai lembaga pendidikan islam tradisional. Layaknya sebuah lembaga pendidikan, pendidikan di surau tidak hanya untuk meningkatkan kemampuan intelektual namun juga untuk membentuk karakter dan kepribadian pemuda Minangkabau. Seperti yang diungkapkan oleh (Azra, 2003) bahwa pendidikan surau adalah sarana untuk bersosialisasi kemudian enkulturasi budaya.

Surau adalah sebuah institusi yang khas dan tipikal Minangkabau. Surau bukan hanya tempat shalat, melainkan tempat anak muda untuk tidur dan mendapatkan "pengajaran". Dimana pengajaran yang nantinya berguna untuk bekal hidup. Di suraulah tempat anak muda berlatih dan memperoleh bekal untuk hidup. Surau sebagai tempat untuk mengaji, belajar pidato dan berpasambahan, mengubah perilaku dari yang bersifat kenak-kanakan ke orang dewasa, dan belajar bersilat. Rantau bertuah yang akan dihadang selepas mendapatkan pengajaran dari surau (Syafri, 2004).

Selanjutnya surau juga berfungsi sebagai Pembentukan watak dan perilaku laki-laki dan perempuan minang; belajar agama, belajar membaca alquran; penggemblengan anak muda membuat mereka tegar dan survive di rantau; membangun interaksi sosial (Latif, 2002).

\section{Budaya Baliak ka Surau}

Kebudayaan tinggal di surau bagi pemuda Minangkabau yang telah memasuki usia sekolah 6 sampai 7 tahun hingga usia 15 tahun banyak melahirkan tokoh pendiri bangsa, khususnya dari Minangkabau seperti Buya Hamka, Tan Malaka , H. Agus Salim, Bung Hatta yang merupakan hasil pendidikan surau. Dari tokoh-tokoh tersebut dapat diketahui bahwa, surau memiliki peranan penting dalam pembentukan karakter individu yang nantinya akan berguna bagi masyarakat.

Namun, dalam perjalanannya pada akhir tahun 50-an, eksistensi surau di Minangkabau mulai menurun dikarenakan pada tahun tersebut terjadi pergolakan di Sumatera Barat yaitu (PRRI) Pemerintahan Revolusioner Republik Indonesia yang mengakibatkan pertumpahan darah. Trauma psikologis di masa Pemerintahan Revolusioner Republik Indonesia (PRRI) akhir 50-an akibat kegagalan menjadi pelopor di PRRI dalam memperjuangkan otonomi dan perimbangan keuangan daerah dengan pemerintah pusat membuat masyarakat Minangkabau mati kutu dan hilang percaya diri. Pada saat pergolakkan PRRI, tentara pusat menjadikan surau sebagai sasaran penyerangan pemuda ditembak (Latif, 2002). Sejak kejadian tersebut, budaya tinggal di surau perlahan hilang ditengah-tengah masyarakat. 
Barulah pada era reformasi keluar UU No. 22 Tahun 1999 tentang Pemerintahan Daerah yang memberikan kebebasan pada masing-masing daerah untuk melalukan revitalisasi nilai-nilai tradisional masing-masing daerah. Budaya baliak ka surau digalakkan seiring dengan budaya baliak ka nagari. (Latif, 2002) mengartikan baliak ka surau dengan bact to basic yaitu kembali ke adat Minangkabau yang menjungjung tinggi falsafah "Adat Basansi syarak, Syarak Basandi Kitabullah".

Dalam perjalanannya sejak dicetuskan hingga saat ini gerakan baliak ka surau belum berjalan sesuai dengan yang diharapkan. Kematangan konsep dan kesesuaian dengan perkembangan zaman menjadi tantangan yang besar. Masyarakat dihadapkan pada arus modrenisasi pendidikan yang membuat eksistensi pendidikan surau menjadi turun dan lama-lama hilang tergerus zaman. Kita semua tentu tidak menginginkan hal tersebut terjadi mengingat kompleksnya nilai-nilai yang ditanamkan pada pendidikan surau. Untuk itu diperlukan pembaharuan dalam menggalakkan budaya baliak ka surau ini. Diantaranya menurut (Azra, 2003) adanya guru yang representatif, manajemen surau yang logis dan dinamis dan kegiatan surau yang realistis.

Pada era reformasi keluarlah Undang-Undang Tentang Pemerintahan daerah yaitu UU No. 22 Tahun 1999 yang memberikan kebebasan pada tiap daerah untuk melakukan revitalisasi nilai-nilai tradisional masing-masing daerah. Sehingga masyarakat Minangkabau kembali menggalakkan budaya yang sempat ditinggalkan, salah satunya budaya tinggal di surau dengan gerakan Baliak ka Surau. Dimana dalam teknis pelaksanaannya direlevansikan dengan kemajuan zaman di abad ke-21 ini.

\section{CONCLUSION}

Budaya tinggal di surau bagi laki-laki Minangkabau yang telah memasuki usia sekolah 6 sampai 7 tahun hingga usia 15 tahun perlu digalakkan kembali melalui gerakan baliak ka surau. Mengingat begitu kompleksnya fungsi dan manfaat surau bagi pemuda Minangkabau. Dimana pendidikan non formal di surau menjadi salah satu faktor mempengaruhi kematangan karir remaja melalui penanaman nilai-nilai kehidupan dengan mengubah perilaku dari yang bersifat kenak-kanakan ke orang dewasa dan pembentukan softskill seperti mengaji, belajar pidato, berpasambahan dan belajar bersilat.

\section{REFERENCES}

Azra, A. (2003). Surau: Pendidikan Islam Tradisi dalam Transisi dan Modernisasi. Jakarta: Tim ICCE UIN Jakarta.

Latif, N. (2002). Etnis dan Adat Minangkabau: Permasalahan dan Hari Depannya. Bandung: Angkasa.

Listyowati, A., Andayani, tri rejeki, \& Karyanta, nugraha arif. (2012). Hubungan antara Kebutuhan Aktualisasi Diri dan Dukungan Sosial dengan KematangAn Karir pada Siswa Kelas XII SMa 2 Klaten.

Munandir. (1996). Program Bimbingan Karir di Sekolah. Jakarta: Depdikbud Direktoral Jendral Pendidikan Tinggi. 
Nurillah, S. A. L. (2017). Program Bimbingan Karir untuk Meningkatkan Kematangan Karir Mahasiswa. Jurnal Inovasi Konseling, 1, 67-85.

Sastrawati, W. U., Kadek, N., Purwanti, C., Suhardita, K., Sapta, I. K., Komang, N., .. Bali, I. P. (2019). Efektivitas Konseling Behavioral Model Krumboltz untuk Mengembangkan Keputusan Karir Siswa, 4(2), 63-67.

Siti S. Fadhilah, R. N. (2010). Model Bimbingan Pengembangan untuk Meningkakan Kematangan Karier Mahasiswa. Pedagogia, (2), 85-102.

Syafri, S. (2004). Minangkabau yang Gelisah. Bandung: CV. Lubuk Agung.

UU No.22 Tahun 1999 tentang Pemerintahan Daerah.

Winkel, W. S. (1997). Bimbingan dan Konseling di Instituti Pendidikan. Jakarta: PT. Grasindo.

Yahya, A., Maalip, H., \& Omar, M. H. (2011). Permasalahan Yang Mempengaruhi Pembelajaran dan Pencapaian Akademik Pelajar Bumiputra ( Tingkatan 4 ) di Sekolah Menengah Teknik di Johor Bahru. Journal of Education Psychology and Counseling, 2(Tingkatan 4), 1-27. 